\title{
Private embryos, public policy
}

In the United States, assisted reproduction and embryo research in the private sector have been left largely unregulated, whereas federally funded labs face stringent controls. The distinction makes little sense.

A s Nature went to press, US voters were going to the polls for the mid-term elections. Embryo research, stem cells and cloning have not been hot campaign topics. But when the victors take their seats in Congress, researchers can be sure that these issues won't stay off the agenda for long.

The Senate has so far failed to pass legislation on cloning to produce either babies or embryonic stem cells. But Senator Sam Brownback (Republican, Kansas), who opposes 'therapeutic cloning', as the latter practice is dubbed, is still committed to the issue. And if, as is feared, the renegade Italian scientist Severino Antinori soon claims that he has cloned a human, advocates of therapeutic cloning face a rough ride. Even if evidence for his claim is not forthcoming, it will not stop Brownback and his allies from seizing an opportunity to pass legislation to restrict a potentially important area of biomedical research.

Scientists have worked with advocates for patients to convince senators such as Dianne Feinstein (Democrat, California) and Orrin Hatch (Republican, Utah) to fight attempts to outlaw therapeutic cloning. Now, however, they should return to the political fray with an expanded vision: to help draft legislation that regulates the broad sweep of embryo research, as well as some aspects of assisted reproduction, in both public and private sectors.

Currently, the private sector is left largely to its own devices. In vitro fertilization clinics, in particular, have been considered off-limits. The right of an individual to reproduce, while not actually enshrined in the US constitution, has generally been held to be inalienable.
But the sands may be shifting. The Bush administration's move to extend the remit of an advisory panel charged with protecting the interest of human subjects in clinical research to cover embryos and fetuses (see page 3) suggests that it is looking again at its hands-off attitude to the private sector - the panel can recommend changes to Food and Drug Administration policies, which affect private-sector researchers. And the President's Council on Bioethics is considering whether changes are needed to the regulatory framework for embryo research.

Individual states have also begun weighing in on the matter. In September, the California legislature passed a law affirming that researchers there can derive new embryonic stem-cell lines, including from cloned embryos, as long as they do not use federal money. Other states are talking about passing similar laws. And while this may seem to benefit researchers, states emboldened by passing such legislation might in future enact restrictive laws on other aspects of research.

At the federal level, meanwhile, the freedom to conduct embryo research lies at the whim of the current and future administrations. Federally funded scientists can now work with certain prescribed embryonic stem-cell lines, under a decree issue by President George W. Bush in August 2001. But that could be revoked at a stroke.

Fully debated federal legislation must be preferable to the current mish-mash. Britain's pioneering 1990 Human Fertilisation and Embryology Act has done a reasonable job of protecting the interests of both embryos and researchers. It's time to consider whether something similar might work in the United States.

\section{Reform by stealth}

The government of Silvio Berlusconi apparently wants to restructure Italian science, but seems uninterested in consultation.

T hese are worrying times for Italian researchers. Not only are they facing the prospect of budget cuts, but a proposal leaked from the research ministry in August has raised the spectre of further political control over the CNR, Italy's national research council.

The news that the right-leaning government of Prime Minister Silvio Berlusconi was planning to restructure Italian science came as a shock. After all, the paint is not yet dry on reforms introduced by the previous centre-left government, which regrouped the CNR's 330 institutes into the hundred that now exist (see Nature 412, 264-265; 2001). The leaked document's content was even more disturbing than its sudden appearance: it proposed dividing the CNR into 15 directorates, the head of each to be appointed by the research ministry, and suggested that a range of other independent agencies and institutes should be rolled into the CNR.

Italian science has long been plagued by a system that appoints the heads of research agencies according to political allegiance, rather than competence. And the prospect of this unwelcome patronage reaching further down into the management of the CNR, and encompassing bodies that currently lie outside the council's influence, has sparked petitions and rallies of protest (see Nature 419, 240; 2002). Guido Possa, deputy minister for research, claimed the document was merely one of a number of very early drafts. But as the weeks have passed with an absence of discernible consultation, few scientists are reassured that the final document, expected to be released later this month, will be significantly different.

So far, all that has emerged is a proposed $2.5 \%$ cut in the publicly funded research budget. What's more, the government proposes to end special funding arrangements for the INFM, an independent agency for research into atomic, molecular and condensed-matter physics created in 1994. As a result, the INFM faces having its core budget slashed by more than a third, while being subsumed into the CNR.

It is all a far cry from the first few months after the Berlusconi administration's election in April last year, when Possa's boss, education and research minister Letizia Moratti, committed to double the research budget over the next five years.

In line with Berlusconi's business-friendly ideology, Possa likes to compare research organizations to profit-making companies. This is misguided. Before it is too late, he should talk with, and listen to, the scientific community, in Italy and abroad, to explain what his government wants to achieve, and to learn how best to make use of his country's highly educated researchers. If he does so, Possa will learn that independence, not tight political control, is the key to success in basic research. He might also be reminded that reforms introduced alongside significant budget cuts are rarely a success. 